\title{
ASPEK-ASPEK SOSIOLOGIK SISTEM HUKUM NASIONAL (Tinjauan Kritis Terhadap Kasus Bank Century)
}

\author{
Noor Aziz Said \\ Fakultas Hukum Universitas J enderal Soedirman Purwokerto \\ E-mail: noor.said@unsoed.ac.id
}

\begin{abstract}
National law system professes the modern precept. The existence of modern law was integrally with the modern concept, which was the analytical legal positivism or the rechtdogmatiek and the political atmosphere which hegemony the XIX century, which is: "Liberalism". Liberalism as a fundament of modern law focused in individual freedom and managing lives by preserving freedom and the sustainably. Liberal values and individual freedom have become paradigm inside the modern law system. And sociologic perspective, modern law existance with liberalism is a reflection of political interaction pattern, economic, social, and culture and preserving the interaction, it clearly that law contain with class characteristic. Law system was not integration media but creating and strenght the undistributed and social jealousy, and instituted privilege. The impact is law interaction no longer reflecting the equal relation but oriented to repressive based on power or asymmetry and negative sanction.
\end{abstract}

Keyword: liberalism, class freedom, repressive, right

\begin{abstract}
Abstrak
Sistem hukum nasional menganut ajaran hukum modern. Kehadiran hukum modern tidak dapat dilepaskan dari konsep hukum modern, yakni analytical legal positivism atau rechtsdogmatiek dan atmosfer politik yang menguasai abad ke XIX, yaitu : "Liberalisme". Faham liberalisme yang melandasi hukum modern berpusat pada kemerdekaan individu dengan menata suatu kehidupan dimana kemerdekaan individu dijamin keberadaan dan kelanjutan keberadaan tersebut. Nilai liberal dan kemerdekaan individu menjadi paradigma dalam sistem hukum modern. Dari perspektif sosiologik, keberadaan hukum modern dengan faham liberalisme merupakan pencerminan pola hubungan politik, ekonomi, sosial, dan budaya serta mewujudkan kondisi bagi pemantapan berlangsungnya hubungan-hubungan itu, maka makin disadari bahwa hukum mengandung ciri-ciri kelas. Sistem hukum bukan merupakan sarana integrasi, tetapi menciptakan dan mengukuhkan ketidak-merataan dan kesenjangan sosial serta melembagakan hak-hak istimewa. Akibatnya, hubungan hukum tidak mencerminkan hubungan yang sederajat atas dasar hak yang sama, melainkan bergeser ke pola represif atas dasar hubungan kekuasaan, yakni asymmetry dan sanksi negatif.
\end{abstract}

Kata Kunci: liberalisme, class, kemerdekaan, represif, hak.

\section{Pendahuluan}

Pasal 1 ayat (3) UUD 1945 menentukan bahwa negara Indonesia adalah Negara Hukum. Pasal 1 ayat (3) UUD 1945 di atas mengandung arti, bahwa Republik Indonesia adalah Negara hukum yang menjunjung tinggi hak asasi manusia dan menjamin segala warga negara bersamaan kedudukannya dalam hukum dan pemerintahan dengan tidak ada kecualinya (equality before the law).

Asas Negara Hukum memiliki tiga prinsip, yaitu pengakuan dan perlindungan hak asasi yang mengandung persamaan dalam bidang politik, hukum, social ekonomi, kultural dan pendidikan; peradilan yang bebas dan tidak memihak; jaminan kepastian hukum dalam semua persoalan. ${ }^{1}$

Proses pembangunan dapat menimbulkan kemajuan dalam kehidupan masyarakat, selain itu dapat juga mengakibatkan perubahan kondisi sosial masyarakat yang memiliki dampak negatif, terutama menyangkut masalah

\footnotetext{
1 Harris Soche, 1985, Supremasi Hukum dan Prinsip Demokrasi di Indonesia, Yogyakarta: Hanindita, hlm. 31.
} 
peningkatan tindak pidana yang meresahkan masyarakat. Salah satu tindak pidana yang dapat dikatakan fenomenal adalah masalah korupsi. Tindak pidana ini tidak hanya merugikan keuangan negara, tetapi juga merupakan pelanggaran terhadap hak-hak sosial dan ekonomi masyarakat. $^{2}$

Konsiderans UU No. 31 Tahun 1999 tentang Pemberantasan Tindak Pidana Korupsi menentukan:

1. bahwa tindak pidana korupsi sangat merugikan keuangan negara atau perekonomian negara dan menghambat pembangunan nasional, sehingga harus diberantas dalam rangka mewujudkan masyarakat adil dan makmur berdasarkan Pancasila dan UUD 1945.

2. bahwa akibat tindak pidana korupsi yang terjadi selama ini selain merugikan keuangan negara atau perekonomian negara, juga menghambat pertumbuhan dan kelangsungan pembangunan nasional yang menuntut efisiensi tinggi.

Meningkatnya tindak pidana korupsi yang tidak terkendali khususnya di era reformasi selama lima tahun terakhir, tidak ada upaya pemberantasan korupsi yang efektif. Ini merupakan hal yang sangat ironis, mengingat tujuan reformasi adalah pemberantasan KKN. Hal ini menunjukkan, bahwa pemerintahan Indonesia belum maksimal untuk memberantas korupsi. Bahkan menurut Political Risk Service's International Country Risk Guide (ICRG), bahwa korupsi di Indonesia sama maraknya atau bahkan lebih buruk dibandingkan dengan ketika Soeharto berkuasa. ${ }^{3}$ Dalam skala internasional, hasil survei Transparency International Indonesia (TII) tahun 2003 menunjukkan, bahwa Indonesia merupakan negara paling korup nomor enam dari 133 negara. Di kawasan Asia, Bangladesh dan Myanmar lebih korup dibandingkan Indonesia. Nilai indeks persepsi korupsi (IPK) Indonesia ternyata lebih rendah $(9,92)$ daripada negara-negara tetangga, seper-

\footnotetext{
2 Evi Hartanti, 2007, Tindak Pidana Korupsi, J akarta: Sinar Grafika, hlm. 1.

3 Pramono et. al, 2005, Membasmi Kanker Korupsi, J akarta: PSAP Muhammadiyah, hlm. 68.
}

ti Papua Nugini $(2,1)$, Vietnam $(2,4)$, Philipina $(2,5)$, Malaysia $(5,2)$, dan Singapura. Sementara itu di tingkat dunia, negara-negara ber-IPK lebih buruk dari Indonesia merupakan negara yang sedang mengalami konflik seperti Angola, Azerbaijan, Tajikistan, dan Haiti. ${ }^{4}$

Hasil survei Political and Economy Risk Consultancy (PERC) terhadap 1000 pengusaha ekspatriat yang bekerja di 12 negara di Asia. Dengan skor 9,92 maka fakta bahwa Indonesia merupakan negara terkorup di Asia semakin sulit untuk dibantah. Di Asia, Singapura sebagai negara terbersih ke-5 $(9,7)$ dan Finlandia sebagai Negara terbersih pertama $(9,8) .^{5}$

Tingginya korupsi di Indonesia telah menyebabkan semua sistem dan sendi kehidupan bernegara rusak karena praktek korupsi telah berlangsung secara merata dan membuat larut hampir semua elit politik. Apabila dibiarkan terus berlangsung dan tanpa tindakan tegas, korupsi akan menggagalkan demokrasi dan membuat negara dalam bahaya karena kehancuran sistem.

Situasi seperti ini semakin sulit bagi Indonesia karena negara ini masih terjebak dalam lingkaran transisi demokrasi yang tak kunjung usai. Padahal, sejak awal 1990-an, persoalan terbesar yang terdapat di negara-negara transisi adalah tampilnya perekonomian gelap (shadow economy). Artinya, terlihat ada aktifitas ekonomi, tetapi sebenarnya di organisasi oleh semacam lembaga tersendiri, termasuk "kabinet malam", istilah untuk orang-orang yang dekat dengan kepresidenan yang tidak mempunyai posisi formal. ${ }^{6}$

Pemberantasan KKN yang berujung maraknya korupsi telah berlangsung sejak tahun 1960, dengan berlakunya Undang-undang Nomor 24 Prp. 1960 yang kemudian disempurnakan dengan Undang-undang Nomor 3 Tahun 1971 dan terakhir disempurnakan oleh Undangundang Nomor 31 Tahun 1999 dengan perubahan via Undang-undang Nomor 20 Tahun 2001. Bahkan pada tahun 2002 pemerintah telah

\footnotetext{
4 Ibid, hlm. x.

5 Evi Hartanti, op. cit, hlm. 3 dan Pramono, et. al, op.cit hlm. IX.

6 Pramono, et. al, ibid, hlm. X.
} 
membentuk lembaga peradilan ad hoc untuk melengkapi jajaran Integrated Criminal J ustice System dengan dikeluarkannya Undang-undang Nomor 30 Tahun 2002 tentang KPK dan lebih dari itu dalam rangka penanggulangan kejahatan pada umumnya, pemerintah telah membentuk komisi-komisi yang bertugas mengawasi kinerja lembaga-lembaga penegak hukum seperti Komisi Yudisial, Komisi Jaksa, Kompolnas dan baru-baru ini Presiden membentuk Satgas Mafia Hukum. Namun semuanya itu sampai kini belum menampakan hasil yang diharapkan dan terkesan lebih merupakan pemborosan keuangan Negara. Meningkatnya korupsi kolusi dan nepotisme diperparah dengan semakin menguatnya globalisasi yang melahirkan pola hidup hedonisme dan konsumerisme.

Globalisasi yang pada dasarnya merupakan kebudayaan kapitalisme, karena fokus globalisasi adalah mekanisme pasar dan konsumerisme. Globalisasi telah merasuk ke Indonesia sejak satu dekade yang lalu dan memulai kampanye dan operasinya ke dalam kebudayaan umum dan pasar, melalui media masa elektronik dan cetak serta melalui berbagai produk luar negeri yang kompetitif harganya dan bergengsi untuk digunakan. Sadar atau tidak globalisasi telah membuka wawasan budaya orang Indonesia di satu pihak, dan dipihak lain globalisasi telah menambah selera dan kebutuhan konsumsi orang Indonesia secara kwalitas dan kwantitas. Selera yang atributatributnya modern dan mahal serta bergengsi dapat digunakan oleh golongan sosial atas untuk memperkuat batas-batas sosialnya dalam hubungannya dengan golongan-golongan sosial lainnya yang lebih asor. Dampaknya adalah dibutuhkannya lebih banyak uang untuk pemenuhan selera dan kebutuhan konsumsi yang meningkat, sedangkan ekonomi Indonesia masih berada dalam masa krisis nasional. Hal yang menarik dari gejala Indonesia adalah tidak adanya perasaan berada dalam masa krisis yang diakibatkan oleh krisis ekonomi nasional, sehingga nepotisme, kolusi, dan korupsi mau tidak mau merupakan satu-satunya jalan yang dapat ditempuh oleh para pejabat dan oknum dalam hubungan-hubungan mereka dengan para pebisnis untuk membiayai berbagai pemenuhan kebutuhan dn selera konsumsi yang meningkat. ${ }^{7}$

Pada awal tahun 2010 bangsa Indonesia dikejutkan dengan terbongkarnya kejahatan di bidang perbankan, yakni Bank Century. Kasus Bank Century melibatkan pejabat teras negara, yakni Wakil Presiden, Menteri Keuangan dan beberapa pejabat tinggi di lingkungan kepolisian serta anggota DPR, yang menyebabkan DPR membentuk panitia khusus. Pemerintah mengeluarkan dana talangan kepada Bank Century sebesar Rp. 6,7 triliun yang kemudian diselewengkan oleh Direktur Bank Century. Sementara itu, hutang luar negeri Indonesia per J anuari 2008 mencapai Rp. 1.600 triliun rupiah (SCTV, 03 Desember 2008, Pkl. 00.35). Untuk sekarang sudah berapa jumlah hutang Indonesia?. Kalau ada pepatah "ibarat gunung es", maka kasus-kasus kejahatan korupsi yang selama ini mencuat ke permukaan itu hanyalah sebagian terkecil saja dari skala yang lebih besar.

Sejak era reformasi yang diawali dengan kejatuhan Presiden Soeharto, Pemerintah telah melakukan reformasi menyeluruh di berbagai bidang kehidupan bernegara, baik di lembaga eksekutif, legislatif maupun yudikatif. Salah satu bidang yang mendapat perhatian utama adalah reformasi di bidang birokrasi. Hal ini mengingat, bahwa bidang birokrasi merupakan tonggak fundamental dalam menyelenggarakan pemerintahan negara. Sebagaimana diketahui, bahwa Indonesia menganut konsep Welfare State yang mempunyai fungsi menyelenggarakan kesejahteraan umum. Secara konstitusional Indonesia adalah negara kesejahteraan terdapat dalam Pasal 33 ayat 1 dan Alinea IV UUD 1945 Amandemen. Dalam menyelenggarakan kesejahteraan umum, penyelenggara negara (eksekutif, legislatif, yudikatif) dituntut untuk mentaati asas-asas umum penyelenggaraan negara yang baik (Algemeen beginselen van behoorlijk bestuur) sebagaimana tersebut dalam

\footnotetext{
Parsudi Suparlan, “Korupsi, Kolusi dan Nepotisme Dalam Perspektif Masyarakat majemuk Indonesia", J urnal Polisi Indonesia Tahun V/ April 2004, J akarta: Program Pascasarjana KIK - UI, hIm. 16-17.
} 
Pasal 3 UU No. 28 Tahun 1999. Arti penting reformasi bidang birokrasi bagi kelangsungan kehidupan bernegara adalah Hadits Nabi.

Sungguh hancur bangsa sebelum kamu disebabkan karena ketika diantara mereka orang yang terhormat mencuri, mereka tidak mempidana, sementara ketika orang lemah diantara mereka mencuri, maka mereka memotong tangan pencuri tersebut. Demi Dzat yang diriku di bawah kekuasaanNya apabila Fatimah binti Muhammad mencuri, sungguh pasti aku potong tangannya. (HR: Imam Ahmad, Imam Muslim, Imam Nasaiy). ${ }^{8}$

Makna yang terkandung dalam Hadits tersebut di atas adalah bahwa dalam hal penegakan hukum, kekuasaan birokrasi (legal structure) merupakan unsur fundamental di samping unsur hukum (legal substance). Penyelenggara negara dijalankan oleh birokrat negara. Dalam hal ini Lord Acton menyatakan "power tends to corrupt, but absolute power corrupts absolutely". ${ }^{9}$

Dari Hadits dan ucapan Lord Acton di atas, jelas bahwa keberadaan lembaga negara penegak hukum merupakan faktor determinan bagi kelangsungan kehidupan berbangsa dan bernegara dalam rangka mencapai dan mewujudkan kesejahteraan umum. Dengan demikian maka personal quality dan profesionality penyelenggara negara mutlak menentukan kelangsungan kehidupan bernegara itu sendiri. Hadits Nabi :

Tidak akan hancur suatu bangsa walau berbuat dzolim dan berperilaku buruk, apabila pemegang kekuasaan jujur dan adil, akan tetapi akan hancurlah suatu bangsa walau bangsa itu jujur dan berbuat baik apabila pemegang kekuasaan berbuat dzolim dan berperilaku buruk. (HR Abu Na'im). ${ }^{10}$

Penyelenggaraan negara dengan kosep Social welfare mencakup bidang-bidang dan sendi-sendi kehidupan sosial yang teramat luas,

\footnotetext{
8 Sayid Sabiq, 1990, Figh Al Sunnah Jilid II, Mesir: Darul Fath, Kairo, hlm. 456

9 Miriam Budiardjo, 1982, Dasar-dasar IImu Politik, Jakarta: Gramedia, hlm. 55.

${ }^{10}$ Muhammad Nawawi, Tanpa Tahun, Nashoihul Ibaad, Bandung: Ma'arif, hlm. 48.
}

sehingga adalah tidak mungkin undang-undang mampu mengatur seluruh kehidupan sosial seperti yang dikatakan oleh Sudikno "Kalaupun undang-undang itu jelas, tidak mungkin undang-undang itu lengkap dan tuntas. Tidak mungkin undang-undang itu mengatur segala kegiatan kehidupan manusia secara lengkap dan tuntas, karena kegiatan kehidupan manusia itu tidak terbilang banyaknya. Kecuali itu undang-undang adalah hasil karya manusia yang sangat terbatas kemampuannya, bahkan sebaliknya undang-undang itu acap kali ketinggalan dari dinamika perubahan masyarakat yang bersifat akseleratif. Sebuah adagium mengatakan : "het recht hinkt achter der feiten aan". ${ }^{11}$ Oleh karena itu, penyelenggara negara diberi hak untuk melakukan tindakan-tindakan kebijakan (police). Kebijakan (police) diartikan "the authoritative allocation of values for the whole society - but it turns out that only the government can authoritatively act on the whole society, an everything the government chooses do or not to do results in the allocation of values". ${ }^{12}$ Dalam hukum administrasi dikenal apa yang disebut vrije bevoegdheid/ freies - Ermessen/ diskresionare. Instrumen hukum ini diberikan adalah sebagai salah satu sarana yang memberi ruang bergerak bagi pejabat atau badan-badan administrasi negara untuk melakukan tindakan tanpa harus terikat sepenuhnya pada undang-undang ${ }^{13}$ dalam rangka menyelenggarakan fungsi pemerintahan, yakni mewujudkan kesejahteraan umum. Keputusan pemerintah lebih mengutamakan tujuan atau sasarannya (doelmatigheid) daripada sesuai dengan hukum yang berlaku (rechtmatigheid). ${ }^{14}$ Di samping vrije bevoegheid merupakan konsekuensi logis dari konsep Welfare state, juga sebagai alternatif untuk mengisi kekurangan dan kelemahan dalam penerapan

\footnotetext{
${ }^{11}$ Sudikno, 1991, Mengenal Hukum, Yogyakarta: Liberty, hlm. 143.

12 Thomas R Dye, 1978, Understanding Public Police, New York: Prentice Hall inc, hlm. 3.

${ }^{13}$ Markus Lukman, 1996, Eksistensi Peraturan Kebijaksanaan dalam Bidang Perencenaan dan Pelaksanaan Rencana Pembangunan di Daerah serta Dampaknya terhadap Pembangunan Materi Hukum Tertulis Nasional, Disertasi, Bandung: Universitas Padj adj aran, hlm. 205.

14 Bahsan Mustafa, 1990, Pokok-pokok Hukum Administrasi Negara, Bandung : Citra Aditya Bakti, hlm. 55.
} 
asas legalitas (wetmatigheid van bestuur). Bagi negara yang bersifat Welfare state, asas legalitas saja tidak cukup untuk dapat berperan secara maksimal dalam melayani kepentingan masyarakat, yang berkembang pesat sejalan dengan perkembangan ilmu dan teknologi. ${ }^{15}$ Menurut Laica Marzuki, freies-Ermessen merupakan kebebasan yang diberikan kepada tata usaha negara dalam rangka penyelenggaraan pemerintahan, sejalan dengan meningkatnya tuntutan layanan publik yang harus diberikan tata usaha negara terhadap kehidupan sosial ekonomi para warga yang semakin komplek. ${ }^{16}$ Lembaga yudikatif dalam hal ini berupa kebebasan pengadilan untuk menggali nilai-nilai yang hidup dan berkembang dalam masyarakat, jurisprudensi dan penafsiran dan konstruksikonstruksi hukum lain, sebagaimana dijelaskan Lie Oen Hock sebagai berikut :

"Dan apabila kita memperhatikan undang-undang, ternyata bagi kita, bahwa undang-undang tidak saja menundjukkan banjak kekurangan-kekurangan, tapi sering kali djuga tidak djelas. Walaupun demikian hakim harus melakukan peradilan. Teranglah, bahwa dalam hal sedemikian undang-undang memberi kuasa kepada hakim untuk menentukan sendiri maknanja ketentuan undang-undang itu atau artinja suatu kata jang tidak djelas dalam suatu ketentuan undang-undang. Dan hakim boleh menafsir suatu ketentuan undang-undang setjara gramatikal atau historis, baik "rechts maupun wetshistoris". ${ }^{17}$

Reformasi birokrasi di lembaga eksekutif, legislatif dan judikatif selama ini masih belum menunjukkan hasil yang diharapkan. Hal ini terbukti dari masih maraknya kejahatan korporasi dan tindak pidana korupsi walaupun

\footnotetext{
${ }^{15}$ Ridwan HR, 2006, Hukum Administrasi Negara, J akarta: Raja Grafindo Persada, hlm. 179.

16 Laica Marzuki, 1996, Peraturan Kebijaksanaan (Beleidsregel) Hakikat serta Fungsinya Selaku Sarana Hukum Pemerintahan, Makalah Penataran Nasional Hukum Acara dan Hukum Administrasi Negara, Ujung Pandang: Fakultas Hukum Universias Hasanudin, hlm. 7.

17 Lie Oen Hock, 1959, Yurisprudensi sebagai Sumber Hukum, Pidato Pengukuhan Guru Besar Luar Biasa tanggal 19 September 1959, Fakultas Hukum dan Pengetahuan Masyarakat, J akarta: UI, hIm. 11.
}

disana sini telah diadakan upaya untuk menjerat para pelaku kejahatan ke pengadilan.

Menurut Lawrence Friedman, sistem hukum (legal system) mengandung tiga elemen dasar, yakni undang-undang (legal substance), struktur (legal structure), dan kultur (legal culture). ${ }^{18}$ Keefektifan suatu sistem hukum adalah diukur dari tiga elemen dasar sistem hukum tersebut. "A legal system in actual operation is a complex organism in which structure, substance, and culture interact" ${ }^{19}$

Penyelesaian kasus Bank Century tidak dapat dilepaskan dari pengaruh aspek-aspek sosiologik yang melatar belakangi sistim hukum nasional dengan paham liberalismenya. Dengan melakukan penelaahan kasus Bank Century akan diketahui aspek-aspek sosiologik dalam penegakan hukum, khususnya hukum nasional. Dalam makalah ini kasus Bank Century hanya sebagai variable antara (intervening variable) dalam pembahasan tentang aspek-aspek sosiologik sistem hukum nasional secara lebih konprehensif.

Berdasarkan uraian tersebut di atas, penulis tertarik untuk membahas mengenai apakah penegakan hukum dalam kasus Bank Century dipengaruhi karakteristik sistem hukum nasional yang menganut falsafah liberal capitalism, sehingga penegakan hukum cenderung menunjukkan ciri-ciri kelas dan represif?

\section{Pembahasan \\ Sistem hukum}

Mengenai sistem hukum (legal system), Wolfgang Friedmann menyatakan "A legal system constitutes an individual system determined by 'an inner coherence of meaning, '.... an integrated body rules ....". ${ }^{20}$ Sementara Lawrence Friedman memberikan pengertian legal system dengan menyatakan: "A legal system in actual operation is a complex organism in which structure, substance and culture interact". Substance is composed of substantive

\footnotetext{
${ }^{18}$ Lawrence M Friedman, 1975, The Legal System : A Social Science Perspective, New York : Russel Sage Foundation, hIm. 14.

$19 \mathrm{Ibid}, \mathrm{hlm} .16$.

${ }^{20}$ Wolfgang Friedmann, 1970, Legal Theory, New York: Columbia University Press, hlm. 16.
} 
(primary) rules and rules about how institution should behave. Structure is the institutional body of the system. Culture is the element of social attitude and values. Structure and substance are real component of a legal system. L.A. Hart mengartikan legal system sebagai "double set of rules, the union of "primary rules" and "secondary rules". Primary rules are norms of behavior, secondary rules are norms about how to enforce them". ${ }^{21}$

Terdapat 8 (delapan) prinsip yang terkandung dalam sistem hukum (legal system), yaitu generality; promulgation; prospective legal operation, i.e., generally prohibition of retroactive lawa; (4) intelligibility and clarity; avoidance of contradictions; avoidance of impossible demands; constancy of the law through time, i.e., avoidance of frequent changes; congruence between official action and declared rule. ${ }^{22}$

Berdasar pengertian legal system di atas, maka dapat dikatakan bahwa pada dasarnya sistem hukum adalah suatu himpunan peraturan perundang-undangan (a set of rules) yang di dalam peraturan perundang-undangan itu mengandung nilai dan struktur. Artinya, bahwa suatu sistem hukum mengandung aspek substansi (rules), aspek struktur dan aspek kultur.

\section{Falsafah Liberalisme Sistim Hukum Nasional}

Sistem hukum nasional menganut ajaran hukum modern. Kehadiran hukum modern tidak dapat dilepaskan dari konsep hukum modern. Berbicara tentang hukum modern tidak dapat dilepaskan kaitannya dengan ajaran positivisme, yakni Analytical Legal Positivism atau Rechtsdogmatiek dan atsmofer politik yang menguasai abad ke XIX, yaitu liberalisme. Aliran positivisme lebih menonjolkan munculnya orde hukum perundang-undangan yang dipicu oleh pengadaan kekuasaan legislatif yang memiliki kekuasaan spesifik untuk membuat undang-undang. Ajaran positivisme melahirkan sebuah adagium: "iedereen wordt geacht de wet te kennen nemo ius ignorare consitur". Asas ini bersumber dari Art. 2 van de Ned. Wek

\footnotetext{
21 Ibid, hlm. 15.

22 Ibid, hlm. 18.
}

Alg. Bepalingen: setiap orang sesudah 20 hari setelah diundangkan dianggap mengetahui akan undang-unadang itu. $^{23}$ Termasuk ke dalam bangunan ajaran positivisme adalah aj aran dust Reine Rechtslehre dari Hans Kelsen yang melahirkan teori hierarkhi peraturan perundangundangan.

".... A legal norm is valid because it is created in a way determined by another legal norm, the latter is the reason of validity of the former. The relation between the norm regulating the creation of another norm and this other norm may be presented as a relationship of super- and sub-ordination, which is a spatial figure of speech. The norm determining the creation of another norm is the superior, the norm created according to this regulation, the inferior norm. The legal order, especially the legal order the personification of which is the State, is therefore not a system of norms coordinated to each other, standing, so to speak, side by side on the same level, but a hierarchy of different levels of norms. ${ }^{24}$

Falsafah liberalisme yang melandasi hukum modern berpusat pada kemerdekaan individu dengan menata suatu kehidupan dimana kemerdekaan individu tersebut dijamin keberadaan dan kelanjutan keberadaan tersebut. Nilai liberal dan kemerdekaan individu menjadi paradigma dalam sistem hukum modern.

\section{Sistim Hukum Nasional Bercirikan Kelas}

Falsafah liberalisme yang dianut sistim hukum nasional yang berorientasi pada kemerdekaan individu mengakibatkan sistim hukum nasional bercirikan kelas. Hukum merupakan pencerminan pola-pola hubungan politik, ekonomi, sosial, dan budaya serta mewujudkan kondisi bagi pemantapan berlangsungnya hubungan-hubungan itu, maka makin disadari bahwa hukum mengandung ciri-ciri kelas (the class character of law); sistem hukum adalah mekanisme yang secara langsung atau tidak langsung melayani kepentingan-kepentingan

\footnotetext{
${ }^{23}$ Fockema Andreae, 1977, Kamus Istilah Hukum, Bandung: Binacipta, hlm. 448.

24 Hans, Kelsen, 1961, General Theory of Law and State, New York: Russell and Russell, hlm. 124
} 
kelas ekonomi dan kelas politik yang dominan. ${ }^{25}$ Dalam keadaan demikian, maka lapisan atau golongan yang dominan akan mencoba untuk mempertahankan kelebihannya dengan cara memaksakan berlakunya peraturan yang dapat menjamin kedudukannya. Semakin tinggi kelompok secara ekonomis dan politik semakin besar pula kepentingan dan pandangannya tercermin dalam hukum.

Pemikiran kritis mengenai studi hukum di dalam masyarakat yang bertolak dari anggapan dasar adanya ciri-ciri kelas pada hukum, serta bukan merupakan sarana integrasi, tetapi justru menciptakan dan mengukuhkan ketidakmerataan dan kesenjangan sosial serta melembagakan hak-hak istimewa. ${ }^{26}$

Adanya ciri-ciri kelas pada hukum sebagai suatu sistem dipertegas oleh pernyataan Ralf Dahrendorf: "The difference in the degree of domination may be, and often is, very great. Basically, however, there remains a twoclass system (within a specified association) that is, those who participate in the authority structure through domination and those who do not through subjection". ${ }^{27}$

Akibatnya adalah sistem hukum dalam penegakannya cenderung menunj ukan karakteristik hukum represif "legal institutions are directly accessible to political power; law is identified with the state and subordinated to raison $d^{\prime}$ etat ${ }^{28}$ dengan pola hubungan yang bersifat hubungan kekuasaan. “... Whatever the deviation from either of the modal characteristic, power relation are still present as long one af two variables, asymmetry, or negative sanction, still remains". ${ }^{29}$

\section{Penegakan Hukum Kasus Bank Century}

Kasus Bank Century melibatkan pejabat negara di lingkungan eksekutif (Menteri Ke-

\footnotetext{
25 Satjipto Rahardjo, 1981, Hukum, Masyarakat dan Pembangunan, Bandung: Alumni, hlm. 19-20.

26 Satjipto Rahardjo, 1982, Hukum dalam Perspektif Sosial, Bandung: Alumni, hlm. 20.

27 Margaret, M, Poloma, 1979, Contemporary of Sociological Theory, New York: Macmillan Publishing Co., hlm. 83.

28 Philippe Nonet, et. al, 1978, Law and Society in Transition: Toward Responsive Law, New York: Harper and Row Publishers, Inc., hlm. 33.

29 Ricard Schermerhoorn, 1964, A Society and Power, New York: Randomhouse, hlm. 12.
}

uangan yang dulu Ketua KSSK dan Wakil Presiden yang dulu Gubernur BI) dan lingkungan legislatif (anggota DPR) serta di lingkungan perbankan (Robert Tantular sebagai direktur Bank Century). Perundang-undangn yang dikenakan adalah UU No. 31 Tahun 1999 dan UU No. 7 Tahun 1992 jo UU No. 10 Tahun 1998. Tak pelak, kasus Bank Century melibatkan lembaga eksekutif, lembaga legislatif, dan kepentingan lembaga perbankan (Bankir/kapitalis). Dengan perkataan lain, kasus Bank Century melibatkan aktor-aktor yang mempunyai jabatan dan/atau kekuasaan yang besar. Kepentingan ketiga aktor tersebut adalah juga kepentingan lembaga dimana aktor-aktor tersebut bekerja. Apalagi dalam hukum administrasi terdapat doktrin, bahwa kebijakan/tindakan yang diambil berdasarkan hukum publik itu melanggar kewajiban hukum di bidang publik, maka tidak dapat dikatakan, bahwa penguasa telah melakukan perbuatan melanggar hukum. Penguasa hanya dapat dimintakan pertanggung jawaban atas perbuatan yang dilakukannya apabila ia bertindak dalam kedudukan yang sama dengan orang biasa. (Arrest Hooge Raad, 29 Mei 1896). Dengan demikian apabila kebijakan yang diambil oleh pejabat publik itu melanggar hukum, maka bukan pejabat publiknya yang ditindak melainkan produk hukumnya yang diuj $\mathrm{i}$ melalui lembaga pengujian yang disebut review (toetsingrecht). Lembaga review mengenal tiga jenis review, yaitu: Pertama, Pengujian oleh badan peradilan (judicial review). Apabila produk hukum itu di bawah undang-undang, judicial review dilakukan oleh Mahkamah Agung (Pasal 31 UU No. 14 Tahun 1985). Apabila produk hukum itu berupa undang-undang, judicial review dilakukan oleh Mahkamah Konstitusi (Pasal 10 UU No. 24 Tahun 2003). Kedua, pengujian oleh badan yang sifatnya politik (political review) dan ketiga, Pengujian oleh pejabat atau badan administrasi Negara (administrative review). ${ }^{30}$

Instrument review ini menjadi penghalang diajukannya pejabat negara (publik) ke pengadilan pidana. Sementara anggota DPR di-

\footnotetext{
30 Ni'matul Huda, 2005, Negara Hukum, Demokrasi dan J udicial Review, Yogyakarta: UII Press, hlm. 73.
} 
jadikan tersangka karena anggota DPR tersebut berasal dari partai yang cukup kecil yang oleh pemerintah koalisi dinilai tidak konsisten dengan amanat koalisi. Sebenarnya perbuatan anggota DPR tersebut dalam ranah hukum perdata karena perbuatan yang dilakukan adalah berkaitan dengan boedel Bank Century sebagai bentuk korporasi. David J. Rachman menyebutkan lima ciri penting korporasi, yaitu merupakan subyek hukum buatan yang memilki kedudukan hukum khusus; memiliki jangka waktu hidup yang tidak terbatas; memperoleh kekuasaan (dari negara) untuk melakukan kegiatan bisnis tertentu; dimiliki oleh pemegang saham; tanggung jawab pemegang saham terhadap kerugian korporasi sebatas saham yang dimiliki. ${ }^{31}$

Apabila anggota DPR tersebut memiliki saham di Bank Century, maka imunitas publicnya sebagai anggota DPR tidak berlaku lagi, dan kepadanya tunduk dan berlaku seutuhnya pada hukum privat. Menurut Arifin bahwa, BUMN/ BUMD itu merupakan badan hukum perdata yang tidak mempunyai kewenangan publik. Kekayaan negara dan daerah yang menjadi modal dalam bentuk saham dari badan usaha tersebut tidak lagi merupakan kekayaan negara atau daerah tetapi telah berubah status hukumnya menjadi kekayaan badan usaha tersebut. Demikian pula kedudukan hukum pejabat pemerintah yang duduk sebagai pemegang saham atau komisaris sama atau setara dengan kedudukan hukum masyarakat biasa atau pemegang saham swasta lainnya. Imunitas publiknya sebagai penguasa tidak berlaku lagi, dan kepadanya tunduk dan berlaku sepenuhnya hukum privat, meskipun saham perusahaan tersebut seratus persen milik negara. ${ }^{32}$

Apabila ada indikasi pidana pada diri anggota DPR, maka kepadanya dipertangung jawabkan pidana karena melakukan tindak pidana umum (KUHP-Pasal 372 KUHP) atau tindak pidana khusus berupa kejahatan perbankan

\footnotetext{
${ }^{31}$ I. S Susanto, 1995, Kejahatan Korporasi, Semarang: BP UNDIP, hlm. 15

32 Arifin P Soeriaatmadja, 2004, Format Fungsi Publik Pemerintah dan Badan-badan Hukum, Makalah Pada Rapat di Kementrian Pendayagunaan Aparatur Negara RI, $10 \mathrm{~J}$ uni 2004, hlm. 3.
}

(UU No. 7 Tahun 1992 jo UU No. 10 Tahun 1998). Apabila tidak ada indikasi pidana, perbuatan anggota DPR memenuhi unsur-unsur Pasal 1365 KUHPerdata (Onrechtmatige overheidsdaad) maka kepadanya dapat dituntut ganti rugi.

Apabila keuangan negara/ daerah yang ditanamkan ke Bank Century tetap dianggap sebagai kekayaan negara atau daerah. hal ini menimbulkan suatu konsekuensi sebagai berikut. Pertama, terjadi perlakuan diskriminatif antara saham dari negara dengan saham yang bukan dari negara. Kedua, menyalahi doktrin hukum perdata yang sudah baku, yaitu bahwa boedel sebuah korporasi dari manapun sumbernya dan apapun bentuknya adalah menjadi milik korporasi. Dengan demikian penyelesaian hukumnya dilakukan dengan tunduk pada ketentuan hukum keperdataan.

\section{Keberadaan Pansus Bank Century}

Berkaitan dengan kasus Bank Century, DPR kemudian membentuk Panitia Khusus (Pansus) DPR sebagai wujud/ konkritisasi hak pengawasan (controling). Kalau diikuti persidanganpersidangan Pansus di DPR, sebagian besar anggota pansus berunjuk gigi dan bersemangat (laksana seorang Jaksa Penuntut Umum dan Hakim) mencecar dengan pertanyaan-pertanyaan yang keras dan terkesan memojokkan pada pejabat yang dihadirkan. Tetapi semuanya itu cenderung lebih bersifat performance karena partai-partai anggota dalam pansus mempunyai kepentingan dengan pihak eksekutif (presiden). Beberapa menteri berasal dari partai koalisi. Di samping itu beberapa anggota DPR potensial untuk dijadikan tersangka. Dalam keadaan symbiose-mutualistic ini sekalipun pada sidang pleno terpilih opsi ketiga (ada indikasi pidana), realisasi dari opsi ketiga tersebut masih perlu ditunggu lebih lanjut. Terlebih-lebih akhir-akhir ini timbul dua peristiwa politik, yaitu: Pertama, direkomendasikannya Menteri Keuangan oleh Bank Dunia untuk menduduki jabatan sebagai direktur managing Bank Dunia; Kedua, Diangkatnya Ketua Umum salah satu partai besar sebagai ketua Setgab koalisi pemerintah; Ketiga, Konon, beberapa 
pejabat teras di Kementrian Keuangan menyatakan kepada The J akarta Post (06 Mei 2010), bahwa menteri keuangan dipaksa untuk mundur dan ditawari oleh Bank Dunia jabatan sebagai jalan keluar terhormat (Kompas 10 Mei 2010, hal. 6, kolom 2). Sementara dengan diangkatnya Ketua Umum salah satu partai besar sebagai ketua Setgab koalisi pemerintah, maka partai tertentu yang sebelumnya vokal menuntut dengan tuntas kasus Bank Century menjadi bersikap lain. Partai tertentu tersebut seperti tetap tegar menghadapi kritikan-kritikan tajam baik dari sesama partai koalisi, partai oposisi, para cendekiawan/akademisi, maupun masyarakat luas. Agaknya sulit untuk mengungkap aliran bail-out Rp. 6,7 triliun, sementara para nasabah yang berjumlah tidak sedikit (yang seharusnya mendapatkan perhatian penuh dari DPR) sepertinya dibiarkan kepentingan mereka demi kepentingan organisasi. Pembiaran terhadap kepentingan para nasabah yang merupakan golongan mayoritas yang tidak berdaya dalam usaha memperoleh kembali hakhak mereka dan lebih mementingkan kepentingan golongan minoritas yang kuat dari segi politik, sosial dan ekonomi adalah indikasi kuat bahwa sistem hukum nasional berbasis class character of law dan tidak sesuai dengan prinsip negara hukum.

Contoh lain untuk mempertegas paham liberalisme sistim hukum nasional adalah kasus pimpinan KPK vs Kepolisian RI. Untuk menyelesaikan kasus ini, Presiden membentuk tim pencari fakta (TPF) yang terdiri dari 8 orang (7 diantaranya adalah pengacara) yang diketuai oleh Adnan Buyung Nasution. Hasil penelitian TPF menyatakan, bahwa tidak cukup bukti pimpinan KPK menerima suap miliaran rupiah. Sementara Kapolri di muka umum menyatakan bahwa alat bukti kuat (lengkap) dan oleh karena itu tidak dapat diterbitkan SP 3. Begitu juga halnya Jaksa Agung, di muka umum dia menyatakan bahwa sudah P21 sehingga tidak dapat diterbitkan SKP 2. Tetapi apa yang terjadi?. Beberapa bulan kemudian J aksa Agung menerbitkan SKP 2, satu diantara tiga pilihan yakni SP 3 dan perkara dikesampingkan demi kepentingan umum (UU Kejaksaan). Pertanyaan yang perlu dikemukakan disini adalah apa status hukum TPF? Apakah hasil TPF mempunyai kekuatan hukum? Ini adalah suatu bentuk intervensi dari pihak eksekutif terhadap Integrated Criminal Justice System. Dua pimpinan KPK berdasarkan Keputusan Presiden dikembalikan lagi pada jabatan semula, sementara Komjen Susno Duadji gara-gara membandingkan KPK dengan Polri laksana cicak dan buaya, dicopot dari jabatannya selaku Kabareskrim Polri karena melanggar kode etik Polri. Apakah karena dia merasa diperlakukan diskriminatif, ia kemudian membongkar mafia hukum dan mafia kasus dalam tubuh Polri yang berakhir dijadikannya Susno Duadji sebagai tersangka dan dijebloskan ke dalam ruang tahanan.

Penegakan hukum yang bersifat represif dan bercirikan kelas juga terjadi di Brazil dalam menyelesaikan konflik-konflik sosial. Konflik sosial yang terjadi di kota Recife merupakan artikulasi dari berbagai 'legalities' dan 'illegalities' dan merupakan perjuangan bagi redistribusi 'legalitas' dan 'illegalitas' yang muncul dari konflik social. Mereka yang menang/dominan adalah mereka yang telah berhasil mengambil alih atau merebut penguasaan atas sarana produksi 'legalitas' dan 'illegalitas' untuk kepentingan mereka sendiri. Dalam menghadapi konflik social ini, tidak segansegan pihak penguasa memobilisir polisi dan militer serta Sekretaris Negara dan Keamanan Publik untuk mempertahankan dominasinya. Kehidupan hukum yang demikian ini pada umumnya terjadi di Negara-negara yang sedang mengalami proses demokratisasi. Hukum mempunyai sifat doubly transparent, yakni sekaligus sebagai ideologi dan utopia, sebagai retrospeksi dan antisipasi, dan sebagai dominasi dan emansipasi. Untuk memahami sifat hukum ini, Santos menyodorkan kombinasi antara hermeneutika negatif (kecurigaan terhadap hukum dan janjijanjinya yang tidak ditepati) dengan hermeneutika positif (berpegang pada hukum yang dianggap sesuai dengan "roh" serta situasi dan kondisi yang spesifik. ${ }^{33}$

\footnotetext{
33 Bonaventura De Saosa Santos, 1995, Toward A New Common Sense: Law, Science And Politic In The Paradigmatic Transition, New York: Roudlege, hlm. 321.
} 


\section{White Collar Crime}

Salah satu ciri kelas dari hukum adalah adanya kejahatan yang disebut White-collar crime. Istilah "White-collar crime" diartikan sebagai "a type of crime committed by the upper or middle classes". ${ }^{34}$ Pada awalnya Whitecollar crime dipakai untuk menyebut kejahatan-kejahatan dalam lingkungan bisnis/ perusahaan/ korporasi. "White-collar crime includes, by way of example, such acts as illegal misrepresentation of the qualities of advertised goods illegal explotationof labour, or violation of the Sherman Anti Trust Act. ${ }^{35}$ Istilah (term) "white-collar crime" diperkenalkan (coined) pada tahun 1941 oleh E.H. Sutherland dengan menyatakan: "A white-collar crime, may be defined approximately as a crime committed by a person of perspectability and high social status in the course of his occupation". - "No collar crime" is the crime of the under privileged: white-collar crime is upper or middleclass crime". ${ }^{36}$

Kejahatan-kejahatan yang masuk dalam kategori White-Collar Crime adalah kejahatan yang berupa illegal abuses of public power dan illegal abuses of economic power seperti pelanggaran terhadap peraturan perpajakan, penipuan terhadap konsumen, pelanggaran terhadap peraturan perburuhan, pencemaran lingkungan, penyelewengan dalam bidang pemasaran dan perdagangan oleh perusahaanperusahaan transnasional dan "penyalahgunaan kekuasaan publik yang bersifat melawan hukum". ${ }^{37}$

Lahirnya White-Collar Crime tidak dapat dilepaskan dari keberadaan hukum modern dan falsafah liberalisme yang mendasari hukum modern. Sebagaimana telah dikemukakan di atas, bahwa hukum modern lebih melindungi kemerdekaan dan kebebasan individu dari pada melindungi kepentingan masyarakat luas.

Dilihat dari segi kedudukan dan jabatan yang dimiliki, pihak-pihak yang terlibat dalam kejahatan Bank Century adalah orang-orang

\footnotetext{
${ }^{34}$ Donald R Taf, 1956, Criminology, New York: Macimillan Publishing Co. Inc, hlm. 251.

35 Ibid.

36 Ibid.

37 I.S, Susanto, op. cit, hlm. 20.
}

yang memiliki status sosial tinggi dan terhormat serta pelanggaran yang dilakukan adalah berkaitan dengan karakter pekerjaan atau jabatan yang ada padanya, dalam arti masih dalam lingkup kewenangannya. Dilihat dari bentuk pelanggaran yang dilakukan, para pelaku dalam kasus Bank Century telah melakukan pelanggaran yang berupa illegal abuses of public power dan illegal abuses of economic power. Bertitik tolak dari dua jenis pelanggaran korporasi ini, kejahatan korporasi adalah termasuk ke dalam kejahatan sosio ekonomi. Dengan tidak mengabaikan kemungkinan adanya pelbagai tindak pidana atas perbedaan karakter, status dan motivasi pelaku, dapat diidentifikasikan beberapa sifat kejahatan sosio ekonomi, yang sedikit banyak akan bermanfaat bagi para penyidik dan penuntut umum.

Pertama, penyamaran atau sifat tersembunyi maksud dan tujuan kejahatan (disguise of purpose or intent). Berbeda dengan kejahatan biasa yang perbuatannya nampak bersifat terbuka dan mudah diinterpretasikan, maka pada kejahatan sosio ekonomi implementasinya seringkali terselubung. Contohnya adalah suap menyuap, yang bisa berupa pelbagai fasilitas dan kesempatan bagi penerima, dan bagi pemberi yang juga dapat berupa badan hukum, suapan tersebut dapat disamarkan dalam bentuk biaya advertensi, promosi dan sebagainya.

Kedua, keyakinan pelaku terhadap kebodohan dan kesembronoan korban (reliance upon the ignorance or carelessness of the victim). Dalam hal ini kurangnya keahlian, kurangnya pengetahuan dan keteledoran korban akan dimanfaatkan oleh pelaku.

Ketiga, penyembunyian pelanggaran (concealment of the violation). Dalam tindak pi-dana biasa, yang menjadi masalah adalah menemukan si pelaku, sedangkan kejahatan sosio ekonomi, seringkali korban baru merasakan bahwa dia merupakan korban viktimisasi selang beberapa lama. Sebagai contoh adalah pelanggaran yang merupakan perbuatan berlanjut. ${ }^{38}$

\footnotetext{
${ }^{38}$ Barda Nawawi Arif, 1992, Bunga Rampai Hukum Pidana, Bandung: Alumni, hlm. 5-6.
} 
Kasus Bank Century sebagai bentuk kejahatan korporasi (sosio ekonomi) telah memenuhi ketiga karakteristik kejahatan sosio ekonomi tersebut. Para pelaku telah menyembunyikan maksud dan tujuan. Adalah patut dipertanyakan, bahwa Bank Century sebagai bank kecil diantara bank-bank yang lain mampu menimbulkan dampak sistemik dan karenanya Pemerintah berkenan memberikan bail-out sebesar Rp. 6,7 triliun dari rencana semula sebesar ratusan miliar rupiah. Ada kecenderungan dari para pelaku, bahwa kebijakan yang pernah dipertanyakan ini berkaitan dengan kekurangtahuan dan kekurang hati-hatian korban khususnya para nasabah bank menyimpan uang di Bank Century. Sementara terbongkarnya kasus Bank Century diawali dengan bangkrutnyaBank Century, sehingga para nasabah tidak dapat mengambil uang simpanannya di bank setelah beberapa bulan atau tahun.

Hukum modern yang mengandung ciri-ciri kelas dan bersifat represif untuk mempertahankan status quo penguasa kerap kali dikemukakan dengan dalih menjamin ketertiban. Aturanaturan hukum bersifat keras dan terperinci, akan tetapi lunak dalam mengikat pembuatnya sendiri. Hukum tunduk pada politik kekuasaan, tuntutan untuk mematuhi hukum bersifat mutlak, ketidak-kepatuhan dianggap sebagai suatu penyimpangan sedangkan kritik terhadap penguasa dianggap sebagai ketidak-kesetiaan. ${ }^{39} \mathrm{Di}$ lain pihak, warga masyarakat sekalipun merupakan golongan mayoritas acap kali tidak memiliki kemampuan untuk mempertahankan hak-haknya yang terlanggar walaupun bagi mereka telah tersedia upaya-upaya hukum untuk mempertahankan hak-hak mereka. ${ }^{40}$ Statemen ini termanifestasikan pada para nasabah Bank Century.

Karakteristik hukum yang bercirikan kelas ini oleh Donald Black digambarkan sebagai suatu proses interaksi antara hukum (=the governmental of social control) dengan aspekaspek sosial lain. Black membagi aspek-aspek

\footnotetext{
39 Ronny Hanitijo Soemitro, 1983, Masalah-masalah Sosiologi Hukum, Bandung: Sinar Baru, hlm. 84.

40 Noor Aziz Said, 1987, Pembebasan Tanah Untuk Pembangunan Jalan di Kota Administratip Purwokerto, Thesis S2, Surabaya: UNAIR, hlm. 71.
}

sosial ke dalam lima aspek, yakni stratifikasi, morphologi, kultur, organisasi, dan kontrol sosial. ${ }^{41}$

\section{Penutup \\ Simpulan}

Berdasarkan uraian tersebut di atas, dapat ditarik suatu simpulan sebagai berikut. Pertama, sistem hukum nasional mengandung karakteristik hukum modern, yakni faham positivisme dengan falsafah liberalisme yang melahirkan orde perundang-undangan. Kedua, sistem hukum nasional cenderung lebih melindungi kemerdekaan dan kebebasan individu dari pada melindungi kepentingan masyarakat luas. Ketiga, dengan karakteristik hukum modern, sistem hukum nasional dalam penegakannya mengandung ciri-ciri kelas (the class character of law). Keempat, kasus Bank Century sarat dengan muatan-muatan sosiologik sebagai konsekuensi logis ciri-ciri kelas sistem hukum nasional yang menganut falsafah liberalisme.

\section{Saran}

Penulis mengajukan saran bahwa pemberdayaan masyarakat sebagai wujud masyarakat madani (civil society) perlu ditingkatkan sebagai kontrol sosial dalam penegakan hukum. Selain itu, dengan meningkatkan pemberdayaan masyarakat diharapkan muatan-muatan sosiologik dalam penegakan hukum dapat diminimalkan.

\section{DAFTAR PUSTAKA}

Andreae, Fockema. 1977. Kamus Istilah Hukum. Bandung: Binacipta;

Arif, Barda Nawawi. 1992. Bunga Rampai Hukum Pidana. Bandung: Alumni;

Black, Donald. 1976. The Behaviour of Law, New York: Akademic Press;

Budiardjo, Miriam. 1982. Dasar-dasar IImu Politik. Jakarta: Gramedia;

Dye, Thomas R. 1978, Understanding Public Police. New York: Prentice Hall inc.;

\footnotetext{
${ }^{41}$ Donald Black, 1976, The Behaviour of Law, Akademic Press, New York-London-Toronto-Sidney-San Fransisco, hlm. 1-2.
} 
Friedman, Lawrence M. 1975. The Legal System: A Social Science Perspective. New York: Russel Sage Foundation;

Friedmann, Wolfgang. 1970. Legal Theory. New York: Columbia University Press;

Hartanti, Evi. 2007. Tindak Pidana Korupsi, J akarta: Sinar Grafika;

Hock, Lie Oen. 1959. Yurisprudensi sebagai Sumber Hukum. Pidato Pengukuhan Guru Besar Luar Biasa tanggal 19 September 1959. Fakultas Hukum dan Pengetahuan Masyarakat. J akarta: UI;

HR, Ridwan. 2006. Hukum Administrasi Negara. J akarta: Raja Grafindo Persada;

Huda, Ni'matul. 2005. Negara Hukum. Demokrasi dan Judicial Review. Yogyakarta: UII Press;

Kelsen, Hans. 1961. General Theory of Law and State. New York: Russell and Russell;

Lukman, Markus. 1996. Eksistensi Peraturan Kebijak-sanaan dalam Bidang Perencenaan dan Pelaksanaan Rencana Pembangunan di Daerah serta Dampaknya terhadap Pembangunan Materi Hukum Tertulis Nasional. Disertasi. Bandung: Universitas Padjadj aran;

Marzuki, Laica. 1996. Peraturan Kebijaksanaan (Beleids-regel) Hakikat serta Fungsinya Selaku Sarana Hukum Pemerintahan. Makalah Penataran Nasional Hukum Acara dan Hukum Administrasi Negara. Ujung Pandang: Fakultas Hukum Universias Hasanudin;

Mertokusumo, Sudikno. 1991. Mengenal Hukum. Yogyakarta: Liberty;

Mustafa, Bahsan. 1990. Pokok-pokok Hukum Administrasi Negara. Bandung: Citra Aditya Bakti;

Nawawi, Muhammad. Tanpa Tahun. Nashoihul Ibaad. Bandung: Ma' arif;

Nonet, Philippe. et. All. 1978. Law and Society in Transition: Toward Responsive Law. New York: Harper and Row Publishers Inc.;

Poloma, Margaret M. 1979. Contemporary of Sociological Theory. New York: Macmillan Publishing Co.;

Pramono. et. all. 2005. Membasmi Kanker Korupsi. Jakarta: PSAP Muhammadiyah;

Rahardjo, Satjipto. 1981. Hukum, Masyarakat dan Pembangunan. Bandung: Alumni;
1982. Hukum dalam Perspektif Sosial. Bandung: Alumni;

Sabiq, Sayid. 1990. Fiqh Al Sunnah Jilid II. Mesir: Darul Fath;

Said, Noor Aziz. 1987. Pembebasan Tanah Untuk Pembangunan Jalan di Kota Administratip Purwokerto. Thesis S2. Surabaya: UNAIR;

Santos, Bonaventura De Saosa. 1995. Toward A New Common Sense: Law, Science And Politic In The Paradigmatic Transition. New York: Roudlege;

Schermerhoorn, Ricard. 1964. A Society and Power. New York: Randomhouse;

Soche, Harris. 1985. Supremasi Hukum dan Prinsip Demokrasi di Indonesia. Yogyakarta: Hanindita;

Soemitro, Ronny Hanitijo. 1983. Masalahmasalah Sosiologi Hukum, Bandung: Sinar Baru;

Soeriaatmadja, Arifin P. 2004. Format Fungsi Publik Pemerintah dan Badan-badan Hukum. Makalah Pada Rapat di Kementerian Pendayagunaan Aparatur Negara RI. 10 J uni 2004;

Suparlan, Parsudi. "Korupsi, Kolusi dan Nepotisme Dalam Perspektif Masyarakat majemuk Indonesia". J urnal Polisi Indonesia Tahun V. April 2004. J akarta: Program Pasca Sarjana Kajian IImu Kepolisian UI;

Susanto, IS. 1995. Kejahatan Korporasi. Semarang: BP UNDIP;

Taf, Donald R. 1956. Criminology, New York: Macimillan Publishing Co. Inc. 